\title{
Insights from the developing world: thrifty genotypes and thrifty phenotypes
}

\author{
Andrew M. Prentice, Pura Rayco-Solon and Sophie E. Moore \\ MRC International Nutrition Group, London School of Hygiene and Tropical Medicine, Keppel Street, London, WC1E 7HT, \\ UK and MRC Keneba, Keneba, The Gambia
}

\begin{abstract}
Few researchers would dispute that the pandemic of obesity is caused by a profound mismatch between humanity's present environmental circumstances and those that have moulded evolutionary selection. This concept was first articulated when gestational diabetes was described as being the result of a 'thrifty genotype rendered detrimental by progress'. More recently, this hypothesis has been extended to the concept of a 'thrifty phenotype' to describe the metabolic adaptations adopted as a survival strategy by a malnourished fetus; changes that may also be inappropriate to deal with a later life of affluence. Both the thrifty genotype and the thrifty phenotype hypotheses would predict that populations in some areas of the developing world would be at greater risk of obesity and its co-morbidities; a proposition to be explored in the present paper. To date thrifty genes remain little more than a nebulous concept propagated by the intuitive logic that man has been selected to survive episodic famine and seasonal hungry periods. Under such conditions those individuals who could lay down extra energy stores and use them most efficiently would have a survival advantage. The search for candidate thrifty genes needs to cover every aspect of human energy balance from food-seeking behaviour to the coupling efficiency of oxidative phosphorylation. The present paper will describe examples of attempts to find thrifty genes in three selected candidate areas: maternally-transmitted mitochondrial genes; the uncoupling proteins; apoE4, whose geographical distribution has been linked to a possible thrifty role in lipoprotein and cholesterol metabolism.
\end{abstract}

Obesity: Thrifty genes: Mitochondrial genes: Uncoupling protein: ApoE

The obesity epidemics of many affluent nations have recently started to coalesce and to engulf many lessaffluent countries. Quite remarkably, it is even penetrating the world's poorest countries in their urban areas (van der Sande et al. 2001), as well as the rural areas of countries a little more advanced along the epidemiological transition. The very high levels of obesity in some of the leastprivileged peoples, in whom circumstance has encouraged a rapid acculturation of diets and lifestyle (e.g. the Pima Indians of Arizona and Nauruan Polynesians), have generated seminal studies of obesity and diabetes over recent decades, and have illustrated the investigative power of studying rapid cultural and behavioural transitions (Bindon \& Baker, 1997; Zimmet et al. 1997). The purpose of the present review is to try to extend these specific examples to a more general interpretation of lessons that might be learnt by considering the early development of the obesity trend within populations assumed to have been adapted to frugal environments until the very recent past. Special attention will be given to the twin concepts of the 'thrifty phenotype' and 'thrifty genotype'.

\section{Thrifty phenotypes}

The thrifty phenotype concept, of an adaptively growthrestricted organism, has existed for many decades but has been most clearly articulated by Hales \& Barker (1992, 2001), who also coined the term 'thrifty phenotype'. The concept has been described in some detail in another paper in this symposium (Stocker et al. 2005), so current comments will be restricted to a few specific observations in relation to the developing country setting.

\footnotetext{
Abbreviations: INS-VNTR, insulin variable number of tandem repeats; UCP, uncoupling protein.

Corresponding author: Professor A. M. Prentice, fax +4420 7958 8111, email Andrew.prentice@1shtm.ac.uk
} 
It is in such countries that the majority of growthrestricted (or small-for-gestational-age) babies are born. The currently-accepted thesis is that this early growth restriction will represent a successful adaptation (although not being without costs) so long as the nutritional circumstances in later life continue to match those that have induced the initial adaptation. Hence, it has been shown in The Gambia that small babies, including those born during a nutritionally-debilitating hungry season, maintain excellent cardiovascular health into adulthood, with a complete absence of the metabolic syndrome, so long as they retain their 'lean, fit and frugal' lifestyle in the rural areas (Moore et al. 2001). In practice, however, this lifestyle is frequently not retained and many individuals who have experienced fetal and early-life nutritional hardships transfer to the urban areas and to a diet of relative energy excess with high intakes of fats and refined carbohydrates (Popkin, 2001, 2002; Adair \& Prentice, 2004). It is this rapid transition within a single lifespan that is implicated by many researchers as a crucial causative agent in the explosion of non-communicable diseases in many such urban areas.

Fetal growth restriction in developing countries has multifactorial origins, but attempts to quantify the contribution attributable to each cause indicate that undernutrition is likely to be the most important single factor (Kramer, 1987, 2003). Both acute and chronic exposures can be critical, although it seems likely that acute energy or nutrient insufficiency has to be quite harsh before it has reproducibly demonstrable effects on the baby (Susser, 1991). Chronic food shortages have their effect by creating a small mother, which imposes 'maternal uterine constraint' on the fetus probably mediated through a complex interplay between insulin-like growth factors and their binding proteins (Kelsey et al. 1999). These constraints attempt to ensure that the fetus does not outgrow the mother's capacity to carry it safely to term and to deliver it naturally. Such growth-restricted babies may be 'small but perfectly formed', and it is incorrect to assume that they necessarily carry the same perinatal risks as a lowbirth-weight baby of a much larger mother (Wilcox, 2001; Melve \& Skjaerven, 2003). They may be thought of as having a harmonious growth well adapted for their uterine environment. Since the uterine environment is itself a reflection of the historic dietary conditions of the family, the baby can be viewed as well adapted to its recent history, and hence to its best available prediction of likely future circumstances.

Problems arise when this harmony of growth is disrupted. The best documented evidence of this disharmony comes from collaborative studies between Ranjan Yajnik and colleagues in Pune, India and Caroline Fall and colleagues in Southampton, UK (Bavdekar et al. 1999; Yajnik, 2000; Yajnik et al. 2002a,b). They have demonstrated a phenomenon that Yajnik (Yajnik et al. 2002a,b) describes as the 'thin-fat' baby syndrome (Prentice, 2003). The Indian mothers are small but carry a disproportionately high level of abdominal fat. Comparison between the Indian and Southampton babies reflects a similar picture, with the Indian babies being much smaller than their UK counterparts in all dimensions except triceps and especially subscapular skinfolds, suggesting that they are relatively fat. Raised glucose and insulin levels are already present in the cord blood of the Indian babies (Yajnik et al. $2002 b$ ) and studies later in childhood also reveal early evidence of insulin resistance (Bavdekar et al. 1999; Yajnik, 2000). There are several possible interpretations of these data, including the possibility that the relative fatness of the small Indian mothers has induced an altered 'disharmonious' pattern of tissue deposition in the fetus that already carries detectable metabolic penalties.

Postnatal influences have so far attracted less interest in the developmental origins of health and adult disease field than prenatal influences. However, they are now beginning to receive much greater attention, in view of the demonstrations that it may be the accelerated catch-up growth of some small babies that is most strongly correlated with later ill-health outcomes (Lucas et al. 1999; Forsén et al. 2000). In the developing world deviations in postnatal growth all tend to be in the downwards direction and, by analogy with the speculations about impaired fetal growth, might also create a disadapted phenotype if such children grow up into conditions of nutrient surfeit. Using data from rural Gambians it has again been demonstrated that there is an absence of any important risk factors for CVD or diabetes in adults who were malnourished as children but still live their traditional frugal rural lifestyle (Moore et al. 2001). This finding holds true even in the lowest quartile of childhood nutritional status, for which the mean weight-for-age Zscore is worse than $-3 \cdot 3$. Such findings do not necessarily challenge the developmental origins of health and adult disease thesis, but do emphasise the need for datasets in which early malnutrition has been followed by later affluence as part of a rapid demographic transition. Until such data are obtained, much of the current prediction that rapidly-developing nations will bear the brunt of the developmental origins of health and adult disease thesis remains speculative.

\section{Thrifty genotypes}

Neel (1962) at the University of Minnesota (Minneapolis, MN, USA) coined the term 'thrifty genotype' in a paper entitled: Diabetes mellitus: a 'thrifty' genotype rendered detrimental by 'progress'. This phrase has become one of those that are sufficiently catchy and self-explanatory to have entered the lexicon and achieved wide currency in both lay and scientific writing. In doing so it has gathered a cloak of misuse that hampers constructive discussion of its possible relevance in understanding the current susceptibility to obesity. An attempt will be made to deconstruct some of this casual usage in order to try and define it better as a theoretical construct. In attempting to do so it is recognised that it may be deprived of one of its major attributes, i.e. a flexibility that has been part of its usefulness.

\section{Generalisability of the thrifty genotype concept}

The disciples of the original thesis of Neel (1962) have frequently argued that it could explain the very high 
prevalence of obesity and diabetes within some isolated populations, particularly on Polynesian islands (West, 1974; Joffe \& Zimmet, 1998). It is argued that the highly-susceptible islanders are the descendants of a few founders who had been selected as the survivors of a long sea crossing in which their less-thrifty shipmates died of hunger. Such a view has been widely held by Western scientists, but refuted as ethnographically inaccurate by Polynesian historians who claim that their forebears were masters of the sea and able to travel indefinitely by catching rainwater and eating fish and turtles (Prentice, 2001).

The issue can be taken a step further and it can be argued that, irrespective of the validity or otherwise of the founder-effect theory in populations with very high susceptibility to diabetes, the metabolic legacy of mankind's struggles against starvation has imparted a much wider influence on the human genome.

Paradoxically, it was the dawn of agriculture that heralded episodes of mass starvation (Diamond, 1993; Prentice, 2001). It is believed that before this time the hunter-gatherer forbears of man avoided starvation by exploiting a highly-varied diet, living in small sustainable groups and being prepared to move to new hunting grounds when the need arose. They undoubtedly would have experienced hunger between successful kills, but would have very rarely been exposed to prolonged starvation. Agriculture, on the other hand, fuelled population growth and diminished dietary diversity (McCance, 1975; Fagan, 2000). This situation is sustainable as long as climatic conditions remain stable (and in the absence of warfare) but is highly vulnerable to even a single year's poor rain, a single night of unseasonable frost or a crop pest or infection such as potato blight.

A selection of the mass of historical evidence that records the influence of widespread catastrophic famine on the human race has been documented in greater detail elsewhere (Prentice, 2001). These records document extreme privation, with frequent references to cannibalism (especially of children) as a means of survival. Some of the earliest and best-known references are the following:

'I am mourning on my high throne for the vast misfortune, because the Nile flood in my time has not come for seven years! Light is the grain; there is a lack of crops and of all kinds of food. Each man has become a thief to his neighbour. They desire to hasten and cannot walk... The counsel of the great ones in the court is but emptiness. Torn open are the chests of provisions, but instead of contents there is air. Everything is exhausted' The Stella of Famine; chiselled into Egyptian rock in the time of Tcheser about 2000BC

'All of Upper Egypt was dying of hunger, to such a degree that everyone had come to eating his children ...the entire country had become like a starved grasshopper..' The Sepulchers of Ankhtifi 2180-60BC

'If there be a cutting down of the food offerings of the gods, then a million men perish among mortals, covetousness is practiced, the entire land is in a fury, and great and small are on the execution block' Middle Kingdom Hymn to the Nile

'And there was famine in the land: And Abram went down into Egypt to sojourn there: For the famine was grievous in all the land' Abram's journey into Egypt; Genesis 12

'...in the city we are exchanging our children and eating them...' China 594BC, The Siege of the Chong Capital

'One could scarcely see the water in the Vistasa, entirely covered as the river was with corpses soaked and swollen by the water in which they had long been lying. The land became densely covered with bones in all directions until it was like one great burial ground, causing terror to all beings' Kashmir in the years 917-8AD as related in Kalhana's 'Rajatarangini'

'Parents killed their children and children killed parents, and the bodies of executed criminals were eagerly snatched from the gallows' Contemporary report from Flanders at the beginning of the Great Famine 1319

'The region has been visited by the exterminating angel. Every scourge has been unloosed. Everywhere I have found men dead of cold and hunger' Mirabeau's report from a visit to Provence immediately before the French Revolution

For greater detail about the effects of starvation the reader is referred to Prentice (2001) or to the two-volume work The Biology of Human Starvation (Keys et al. 1950). Excellent summaries of individual famines are also available (for example, see Jordan, 1996). Only the salient points will be considered here, namely: (a) there is widespread evidence that starvation and famines must have exerted a strong selection effect on the human genome. This effect on the genome would have occurred through suppression of fertility as well as actual mortality; (b) these famines should not be viewed as something happening only in far-off places or in far-off times. Keys et al. (1950) estimate that there have been $>190$ documented famines in Britain alone over the past 2000 years; (c) that whilst in many respects the human genome has remained very stable over the evolutionarily-trivial time of 12000 years, since the dawn of agriculture, it is contended that the approximately 600 generations during this time will have been sufficient to permit considerable selection of 'thrifty genes', especially if mediated through effects on reproduction (as will be argued later). In summary, in concurrence with Darwin (1989) famine should be placed among the three major drivers of natural selection. In the concluding remarks to The Origin of Species Darwin (1989; originally published in 1859) notes that 'The evolution of higher animals directly follows ... from the war of nature, from famine and death ...'.

Having established that there is ample evidence that natural selection could have favoured the selection of thrifty genes, the next task is to deconstruct the concept in an attempt to define it more precisely. The first stage in this process is to address a logical corollary of 'thrifty 
genes' that at first sight seems surprising, i.e. that to believe in thrifty genes is to accept that the natural state of affairs is unthrifty; why might this situation exist?

\section{Belief in 'thrifty genes' implies that the normal state is unthrifty}

It is unlikely that evolution has left man in a physiologically-unthrifty state through simple carelessness. Instead, it is much more likely that there is a series of reasons for energetic profligacy, the advantages of which outweigh their energy costs. Some possible candidates are listed in Table 1; there are no doubt many more candidates.

The fructose-1,6-biphosphatase-phosphofructokinase shuttle is the most famous example of a so-called 'futile cycle' in which substrate is utilised without a net gain in ATP. The favoured teleological explanation for this apparently 'futile' cycle is that it enhances metabolic control enabling substrate to be rapidly provided, since one side of a rapidly-shuttling cycle can be shut down (hence diverting substrate) much more rapidly than the other side could be started up. Similar lines of argument are used to explain why the extrahepatic extra-adipocyte fatty acid cycle circulates much more substrate than is required (Wolfe et al. 1990), and to explain the high rates of muscle glutamine cycling (Parry-Billings \& Newsholme, 1991; Newsholme, 1994).

Substrate usage for thermoregulatory thermogenesis is an obvious reason to maintain an unthrifty state in small and cold-adapted animals, but is probably of limited importance in man.

The need to quench oxidant stress, especially in the mitochondria, may also require a profligate use of reduced substrates. Brand and colleagues (Brand, 2000) have shown that all mammalian organisms so far studied appear to have a high rate of proton leakage across the mitochondrial inner membrane. In his 'uncoupling to survive' hypothesis Brand (2000) argues that this 'inefficiency' is necessary to counteract the high levels of reactive oxygen species generated during normal mitochondrial metabolism.

Another well-known reason that an organism might need to intentionally burn off energy is in order to concentrate diets with inadequate levels of protein or micronutrients.

Table 1. Possible evolutionary benefits of energy or substrate profligacy

\begin{tabular}{l}
\hline Enhancement of metabolic control \\
Whole-body fatty acid cycling \\
Glutamine cycling and immunity \\
Fructose-1,6-biphosphatase-phosphofructokinase \\
Thermoregulatory thermogenesis \\
Brown adipose tissue (UCP1) \\
UCP2 and UCP3? \\
Fructose-1,6-biphosphatase-phosphofructokinase \\
Shivering \\
Quenching oxidant stress \\
Needs high levels of mitochondrial proton shuttling \\
Balancing nutrient-deficient diets \\
Excess energy must be burnt off to 'concentrate' nutrients \\
\hline UCP, uncoupling protein.
\end{tabular}

This possibility was demonstrated many decades ago by McCance and colleagues (Widdowson \& McCance, 1974), and more recently Dulloo (Dulloo \& Jacquet, 2001) has re-presented some of Stock's early data to suggest that the protein level of the diet is also a key mediator of adaptive thermogenesis in man.

Behavioural unthriftiness can also be added to the metabolic unthriftiness listed in Table 1. The young of most species expend high levels of energy in apparentlyunnecessary play, but this activity almost certainly has a vital role in the development of their motor and cognitive skills.

In summary, it is possible to construct many arguments to explain why the normal physiological state would utilise an extent of unthriftiness. Such traits will presumably have been selected for in natural selection's pursuit of optimum performance. Thus, thrifty genes will only have been selected if there is a more powerful selective force at play, i.e. famine.

\section{The multiple possible forms of thrift}

One of the problems of using the 'thrifty gene' concept is that most individuals associate it with a metabolic trait related to a frugal utilisation of fuel, which indeed was Neel's (1962) first intention. However, the phrase could equally well encapsulate broader traits, including behavioural ones that would favour survival during famine and hence could become selected in the genome. A selection of possibilities is listed in Table 2. It should be noted that these examples could operate on the intake side of the energy balance equation, although such genes, for which there is considerable evidence (Snyder et al. 2004), might best be termed 'greedy genes'. Other researchers believe that genes operative on the expenditure side of the equation may operate through an effect on individuals' propensity for physical activity (Chakravarthy \& Booth, 2004).

Having emphasised this important point about the likely pleiotropy of thrifty genes the remainder of the present paper will concentrate on the possible metabolic aspects.

\section{Characteristics predicted for a thrifty gene}

A good candidate as a thrifty gene should exhibit two important features. The first is plasticity in response to environmental circumstances. A gene that is highly thrifty and always in its switched-on mode would presumably lead to gross obesity. While the extra fat stores would aid survival through famine they would, at extreme levels, impair reproductive performance in both males and females. The second feature that would be expected is evidence of 'signatures of selection' such as striking geographical distribution.

Table 2. Examples of the forms 'thriftiness' can take

Metabolic: 'energy-sparing' super-efficient metabolism Adipogenic: propensity to rapid fat gain Physiological: ability to switch off non-essential processes Gluttony: tendency to gorge when food is available Slothfulness: tendency to conserve energy through inactivity Behavioural: hoarding, meanness, theft, etc. 
Table 3. Possible sites for metabolic thrift

Substrate cycling

Mitochondrial proton leakage

Coupled $v$. uncoupled oxidative phosphorylation

$\mathrm{Na}^{+} / \mathrm{K}^{+}$pumping

Cellular repair (e.g. protein turnover)

Reduction in non-essential processes (e.g. immunity)

Fuel channelling: muscle $v$. adipose tissue

\section{Possible candidates for metabolic thrifty genes}

Table 3 lists some of the possible sites and functions from which an organism might withhold energy when times are harsh. The tightening up of efficiency in these areas might be only a temporary phenomenon (e.g. in limiting resources allocated to cognate cell-mediated immunity). In making such savings the organism would essentially be taking a gamble that it could weather the current famine and survive to continue to reproduce when the environmental conditions improved.

Within the areas listed in Table 3 several authors (for example, see Auwerx, 1999; Corbo \& Scacchi, 1999; Ong \& Dunger, 2000; Kimm et al. 2002) have made claims for specific 'thrifty genes'. Some of these claims are misleading, and hence extremely unhelpful, since they apply the concept in an imprecise manner. For instance, it has been stated that '...PPAR $\gamma$ was shown to have a key role in adipogenesis and be a master controller of the 'thrifty gene response' leading to efficient energy storage.' (Auwerx, 1999), but no evidence is provided to suggest that PPAR $\gamma$ has been selected for thrift or exhibits any of the defining characteristics set out earlier. Hence, emphasis will be given to several candidates with more specific, albeit very early, evidence that they may make good candidates for thrifty genes.

\section{Genes regulating fuel channelling}

Neel's (1962) original ideas focused on the possibility that alterations in the insulin signalling pathway could modulate fuel channelling between utilization and storage, and hence provide a likely mechanism for rapid fuel deposition in times of plenty. (This general idea also underlies the Hales \& Barker $(1992,2001)$ thrifty phenotype concept.) The entirety of the insulin signalling pathways are complex and contain many possible candidate genes, although to date none has been reliably pin-pointed as such.

An interesting candidate that is currently being investigating in our Gambian studies is the insulin variable number of tandem repeats (INS-VNTR) microsatellite (Bell et al. 1984). This gene lies on the promoter region of the insulin gene and is upstream of the gene encoding insulin-like growth factor 2 . In non-African populations there are only three main lineages (classes I, II and III), based on the number of repeat motifs, and class I predominates (Stead et al. 2003). Associations have been reported with both type 1 and type 2 diabetes (Bell et al. 1984; Bennett et al. 1995; Ong et al. 1999). In contrast, African populations possess at least twenty-one different variants, with class III predominating (Stead et al. 2003).
The INS-VNTR class III variant has been associated with higher birth weight (Dunger et al. 1998; Lindsay et al. 2003), although recent reports have failed to replicate this finding (Bennett et al. 2004; Mitchell et al. 2004), and faster postnatal growth (Ong et al. 2004a). It will be argued that genes regulating fetal growth and survival may be particularly central to lineage survival in the face of famine, and that INS-VNTR may be a good candidate.

\section{Mitochondrial genes}

Oxidative phosphorylation within the mitochondrion does not achieve $100 \%$ conversion of the potential energy of fuel into ATP, because of uncoupling of the electrontransport chain and the leakage of electrons. The extent of mitochondrial coupling, and any genes that might affect it, probably therefore represent a fertile hunting ground for thrifty genes. There is evidence for striking geographical variation in some mitochondrial genes (Ruiz-Pesini et al. 2004), although the current interpretation is that the variations have been driven by the need for unthriftiness in order to drive thermogenesis and allow the carriers to colonise more northerly latitudes.

In a paper entitled: Effects of purifying and adaptive selection on regional variation in human mitochondrial DNA, Wallace and his team (Ruiz-Pesini et al. 2004) have used phylogenetic analysis of global human mitochondrial DNA to show that mitochondrial DNA lineages from higher latitudes are most highly conserved. These variations correlate with energy deficiency diseases and longevity. The authors conclude that 'Specific mtDNA replacement mutations permitted our ancestors to adapt to more northern climates, and these same variants are affecting our health today' (Ruiz-Pesini et al. 2004). It has further been speculated that the development of these high-energy-requiring unthrifty variants may have driven the appetite for, and development of, high-fat diets.

This example is the best one so far of the sort of genetic detective work that will be necessary to ultimately validate or refute Neel's (1962) hypothesis. The fact that it has apparently identified unthrifty genes rather than thrifty genes does not detract from the principle that analogous thrifty variants may ultimately be identified, and that the mitochondrion is a likely target, whether through mitochondrial or nuclear DNA variation.

\section{The uncoupling proteins 2 and 3}

The original mitochondrial uncoupling protein from brown adipose tissue, uncoupling protein (UCP) 1 , is generally thought to be of limited importance in man beyond the very early neonatal stage (Dalgaard \& Pedersen, 2001; Dulloo \& Samec, 2001; Argiles et al. 2002). The more recent discovery of its homologues UCP2 and UCP3, which are expressed more widely including in adipose tissue and muscle, initially created great interest as possible 'obesity genes' (and by inference thrifty genes) (Dulloo \& Samec, 2001). Subsequent research, however, has yielded a confused picture, which is summarised briefly in Table 4. Certain observations of the phenotypic 
Table 4. The uncoupling proteins (UCP): a confusing picture at present

UCP-knock-out models have unexpected phenotypes UCP2 and UCP3 mRNA up regulated by fasting

Possible role in mitochondrial fatty acid shuttling (UCP3)

Possibly reduce fatty acid accumulation (UCP3)

Possibly enhance muscle fatty acid oxidative capacity (UCP3)

Probably quench reactive oxygen species (UCP2)

Possible immunological role (UCP2)

behaviour, for instance that UCP3 is up regulated not down regulated by fasting, imply that these UCP are not a straightforward component of the energy regulatory apparatus as had first been anticipated (Dulloo \& Samec, 2001). Instead, they may have more esoteric roles such as the quenching of oxidant stress. These latest insights may argue against their candidacy as thrifty genes.

Notwithstanding this argument, there has been interest in the possibility of identifying thrifty traits within the UCP, but little has emerged. Suggestive evidence has been obtained that a UCP3 exon 5 variant is associated with lower resting energy expenditure in African-American women (but not white women) and hence may be a thrifty allele. This evidence was, however, based on a small sample size and, judging by the history of such genetic observations, is unlikely to replicate in future studies (Kimm et al. 2002). Currently, there appear to be no other similar claims.

\section{ApoE}

The global distribution of apoE4 (the variant associated with raised cardiovascular risk) shows a signature of selection of the type predicted for a good functional thrifty gene candidate (Table 5). ApoE2 is most common in the Mediterranean basin where agriculture is thought to have begun. ApoE4 (the ancestral lineage) is more common in pigmies, the Khoi San, Aboriginals, some Native Americans and Lapps, leading Corbo and colleagues (Corbo \& Scacchi, 1999) to speculate that it could represent a more lipid-thrifty variant that is more efficient in sequestering cholesterol and has been better maintained in populations with a tenuous dietary supply. (This argument runs counter to the thesis that it is agricultural societies that are more susceptible to episodic famine; see also the 'famine' quotes concerning the Mediterranean basin listed earlier (see p. 155).)

Corbo (Corbo et al. 2004a,b) argues that the selection effect may be mediated through the fact that the apoE4 variant favours steroidogenesis and hence fertility. In

Table 5. ApoE: evidence of 'signatures of selection'

ApoE2 most common in Mediterranean basin
ApoE4 (the ancestral lineage) more common in:
Pigmies Khoi San
Aboriginals
Some Native Americans
Lapps
ApoE4 associated with increased steroidogenesis and fertility

support of this argument Corbo et al. (2004a) have shown in a random sample of post-menopausal women that carriers of apoE4 had more children than women with apoE2.

This conjecture in relation to reproductive efficiency leads to the final observation to be offered in relation to the search for thrifty genes; that it is highly likely that the best candidates will be associated in some way with reproductive efficiency (see p. 159). Before addressing this topic it is pertinent to comment on a recent hypothesis proposed to explain the differential diabetes susceptibility rates in European and non-European peoples.

\section{The double puzzle of diabetes}

In a recent essay Diamond (2003) has addressed the puzzle of why Europeans seem to have lower susceptibility to type 2 diabetes than other races, after allowing for differences in BMI. Some of the generic data cited are summarised in Table 6. Diamond (2003) downplays the likely contribution of thrifty genes or thrifty phenotypes in the non-Europeans and instead suggests that peoples of European origin must have passed through previous times in which epidemics of diabetes have selected resistant individuals. This explanation would seem to be highly unlikely on the grounds that it is known that an epidemic of diabetes would have to be driven by an epidemic of obesity (and there are no previous records of such), and that in any case diabetes generally kills after the time of peak reproductive performance.

\section{Famines and reproduction}

Severe and extended energy depletion shuts down the reproductive axis in both genders of many (probably most) species, including man. The adults concentrate all available resources on their own survival in the hope that conditions will improve and allow them to recommence active reproduction in the future. Consequently, conception and birth rates fall precipitately during extreme famine, and these variations have been closely documented, using hospital records, in the Dutch Hunger Winter (Stein et al. 1975) and some of the Bengal famines (Sen, 1981; Maharatna, 1996). The fact that this effect is specific to famine, rather than a side-effect of the general horror of the times, has been elegantly illustrated by an analysis of church registers of marriages, births and deaths in Keswick (northwest England) during the Tudor and Stuart famine of

Table 6. Diabetes rates (\% population) for Europeans, who seem to have lower susceptibility to type 2 diabetes, and those of other races (see Diamond, 2003)

\begin{tabular}{lr}
\hline Europeans: UK & 2 \\
$\quad$ Germany & 2 \\
Australia & 8 \\
USA & 8 \\
Pacific Islanders: Nauru: 1952 & 0 \\
& 2002 \\
Aborigines: Traditional & 41 \\
$\quad$ Westernised & 0 \\
Asian Indians: Urban & 23 \\
\hline
\end{tabular}




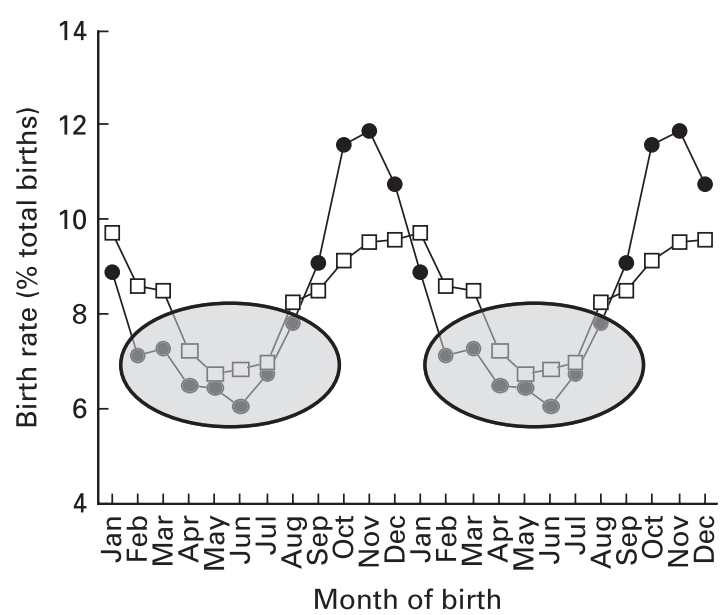

Fig. 1. Possible selective effects of seasonal variations in fertility. (๑), Bangladesh; ( $\square$ ), The Gambia. (০), Data suggest the possibility that only 'thrifty' parents are able to reproduce at bad times.

1623 (Appelby, 1978). The Tudor famine caused a 5-fold increase in mortality and a coincident 3-fold drop in conceptions (as judged by the number of christenings). An outbreak of plague that occurred just 23 years later caused a very similar increase in deaths, but no change in birth rate until a few years later.

Any genetic trait that allows certain women to continue to reproduce in energy-depleted circumstances when others around them have stopped could be viewed as thrifty. The example of apoE4 given earlier could be one such gene. Fig. 1 illustrates how such genes could have been under continuous selection in addition to the episodic selection of catastrophic famines. It shows the very strong seasonal variation in birth rates in two populations exposed to seasonal agricultural patterns, in Bangladesh and The Gambia. The precise reason for this striking variation is not known with certainty. However, in The Gambia it is entirely consistent with the Frisch (1982) hypothesis of suppressed fertility during times of maternal energy depletion, since the lowest birth rate falls exactly 9 months after the time of greatest maternal weight loss during each year's hungry season. The implication is that there are some women who manage to conceive all year round, whilst others are constrained to the more energy-replete season of the year. Do these women have a thrifty trait? Does this trait result in greater overall fertility? These issues are currently under analysis.

There is an additional reason to believe that genes influencing reproduction and fetal well-being are likely candidates for selection by famine. This aspect is illustrated in Fig. 2, which shows some available approximations for oocyte, embryo and fetal losses in normal human pregnancies. It shows the little-appreciated fact that the majority of natural selection of human genes probably occurs before birth. If this concept is valid, then genes favouring fetal survival will be under very strong selective pressure. This explanation would be consistent with some of the previous observations that metabolic plasticity is probably maximised during pregnancy (Prentice \& Goldberg, 2000).

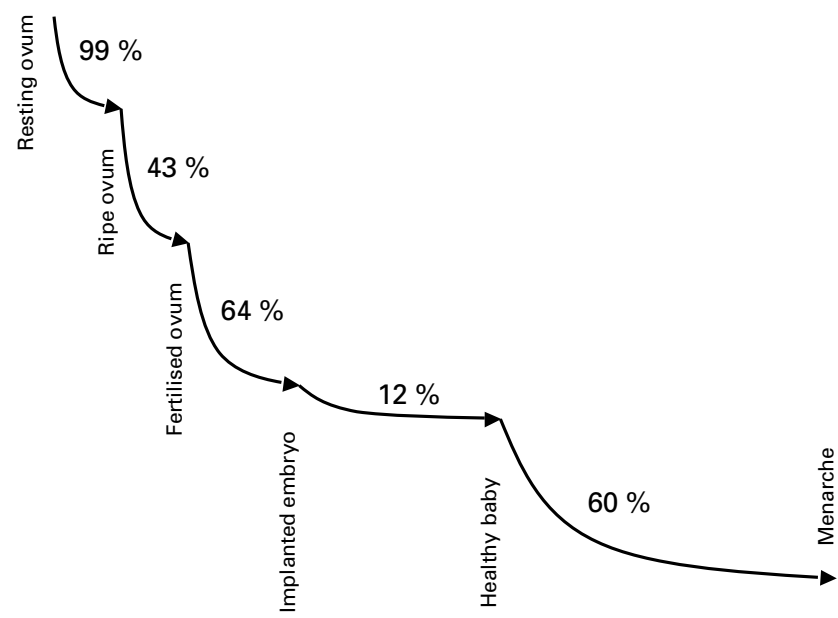

Fig. 2. Some available approximations for oocyte, embryo and fetal losses (attrition rate) in normal human pregnancies, indicating that most genetic selection probably occurs before birth in man. Odds of any ovum producing a grandchild 0.0007.

In studies in progress in The Gambia it is speculated that the class III allele of INS-VNTR may be one such variant if it favours more rapid fetal growth. It is also speculated that it may be associated with the ability to conceive in the hungry season and hence may show different allelic frequencies according to month of birth. Evidence already exists that INS-VNTR may have an important role in modulating fetal survival because it is one of the first genes shown to display differential transmission. Eaves et al. (1999) have shown that the offspring of heterozygous class III/class I parents have a skewed ratio with $54 \%$ class I $v .46 \%$ class III alleles. Such a marked transmission bias indicates a remarkably profound effect, which presumably must be offset by a reverse selection in postnatal life in order to explain the persistence of the class III variant. The class I allele is associated with higher insulin expression in the fetal pancreas (Vafiadis et al. 1996) and insulin-like growth factor 2 in the placenta (Paquette et al. 1998), which may increase the chances of survival of the fetus (Eaves et al. 1999). However, the class I allele has also been associated with low birth weight and increased androgen levels before puberty, which may increase risk for later adult disease (Ibanez et al. 2001; Ong et al. $2004 a, b)$.

Table 7 lists some of the other candidate genes that are currently being investigated in relation to possible effects on fertility.

Table 7. Some known genetic regulators of pregnancy outcome?

Fetal growth: INS VNTR

MODY

GCK-30

$\mathrm{mt} 16189$

G protein $\beta 3$-subunit (825T)

Fecundity: Twinning genes

ApoE

Fetal survival: INS VNTR

INS VNTR, insulin variable number of tandem repeats; MODY, maturity-onse diabetes of the young; GCK, glucokinase; mt, mitochondrial. 


\section{Conclusions}

The twin concepts of 'thrifty phenotype' and 'thrifty genotype' each have merit insofar as they are based on intuitively-attractive ideas that, in the broadest of terms, have plenty of support within biology. Each theory, however, currently lacks the level of precise evidential support that will be needed to transform them from hypothesis to accepted fact. In the continued search for such evidence, which may ultimately inform the understanding of individual variability in susceptibility to obesity and hence to refined therapeutic strategies, it is likely that research in the developing world will be most fruitful. In the present review an attempt has been made to suggest some guidelines to inform a more efficient search.

\section{References}

Adair L \& Prentice AM (2004) A critical evaluation of the fetal origins hypothesis and its implications for developing countries. Journal of Nutrition 134, 191-193.

Appleby A (1978) Famine in Tudor and Stuart England. Liverpool: Liverpool University Press.

Argiles JM, Busquets S \& Lopez-Soriano FJ (2002) The role of uncoupling proteins in pathophysiological states. Biochemical and Biophysical Research Communications 293, 11451152.

Auwerx J (1999) PPARgamma, the ultimate thrifty gene. Diabetologia 42, 1033-1049.

Bavdekar A, Yajnik CS, Fall CHD, Bapat S, Pandit AN, Deshpande V, Bhave K, Kellingray SD \& Jogelkar CV (1999) Insulin resistance in 8 year old Indian children. Diabetes 48, 2242-2249.

Bell GI, Horita S \& Karam JH (1984) A polymorphic locus near the human insulin gene is associated with insulin-dependent diabetes mellitus. Diabetes 33, 176-183.

Bennett AJ, Sovio U, Ruokonen A, Martikainen H, Pouta A, Taponen S, Hartikainen AL, King VJ, Elliott P, Jarvelin MR \& McCarthy MI (2004) Variation at the insulin gene VNTR (variable number tandem repeat) polymorphism and early growth: studies in a large Finnish birth cohort. Diabetes $\mathbf{5 3}$ 2126-2131.

Bennett ST, Lucassen AM, Gough SC, Powell EE, Undlien DE, Pritchard LE et al. (1995) Susceptibility to human type 1 diabetes at IDDM2 is determined by tandem repeat variation at the insulin gene minisatellite locus. Nature Genetics 9, 284-292.

Bindon JR \& Baker PT (1997) Bergmann's rule and the thrifty genotype. American Journal of Physical Anthropology 104, 201-210.

Brand MD (2000) Uncoupling to survive? The role of mitochondrial inefficiency in ageing. Experimental Gerontology 35, 811-820.

Chakravarthy MV \& Booth FW (2004) Eating, exercise, and 'thrifty' genotypes: connecting the dots toward an evolutionary understanding of modern chronic diseases. Journal of Applied Physiology 96, 3-10.

Corbo RM \& Scacchi R (1999) Apolipoprotein E (APOE) allele distribution in the world. Is APOE*4 a 'thrifty' allele? Annals of Human Genetics 63, 301-310.

Corbo RM, Scacchi R \& Cresta M (2004a) Differential reproductive efficiency associated with common apolipoprotein $\mathrm{E}$ alleles in postreproductive-aged subjects. Fertility and Sterility 81, 104-107.
Corbo RM, Ulizzi L, Scacchi R, Martinez-Labarga C \& De Stefano GF (2004b) Apolipoprotein E polymorphism and fertility: a study in pre-industrial populations. Molecular Human Reproduction 10, 617-620.

Dalgaard LT \& Pedersen O (2001) Uncoupling proteins: functional characteristics and role in the pathogenesis of obesity and type II diabetes. Diabetologia 44, 946-965.

Darwin C (1989) The Origin of Species. London: Wordsworth Editions Ltd.

Diamond J (1993) Agriculture's mixed blessings. The Third Chimpanzee, pp. 180-191. New York: Harper Perennial.

Diamond J (2003) The double puzzle of diabetes. Nature 423, 599-602.

Dulloo A \& Samec S (2001) Uncoupling proteins: their roles in adapataive thermogenesis and substrate metabolism. British Journal of Nutrition 86, 123-139.

Dulloo AG \& Jacquet J (2001) An adipose-specific contribution of thermogenesis in body weight regulation. International Journal of Obesity 25, Suppl. 5, S22-S29.

Dunger DB, Ong KK, Huxtable SJ, Sherriff A, Woods KA, Ahmed ML, Golding J, Pembrey ME, Ring S, Bennett ST \& Todd JA (1998) Association of the INS VNTR with size at birth. ALSPAC Study Team. Avon Longitudinal Study of Pregnancy and Childhood. Nature Genetics 19, 98-100.

Eaves IA, Bennet ST, Forster P, Ferber KM, Ehrmann D, Wilson AJ, Bhattacharyya S, Ziegler AG, Brinkman B \& Todd JA (1999) Transmission ratio distortion at the INS-IGF2 VNTR. Nature Genetics 22, 324-325.

Fagan B (2000) Floods, Famines and Emperors. London: Pimlico.

Forsén T, Tuomilehto J, Reunanen A, Osmond C \& Barker D (2000) The fetal and childhood growth of persons who develop type II diabetes. Annals of Internal Medicine 33, 176-182.

Frisch RE (1982) Malnutrition and fertility. Science 215, 1272-1273.

Hales CN \& Barker DJP (1992) Type 2 (non-insulin-dependent) diabetes mellitus: the thrifty phenotype hypothesis. Diabetologia 35, 595-601.

Hales CN \& Barker DJP (2001) The thrifty phenotype hypothesis. British Medical Bulletin 60, 5-20.

Ibanez L, Ong K, Potau N, Marcos MV, de Zegher F \& Dunger D (2001) Insulin gene variable number of tandem repeat genotype and the low birth weight, precocious pubarche, and hyperinsulinism sequence. Journal of Clinical Endocrinology and Metabolism 86, 5788-5793.

Joffe B \& Zimmet P (1998) The thrifty genotype in type 2 diabetes: an unfinished symphony moving to its finale? Endocrine 9, 139-141.

Jordan WC (1996) The Great Famine: Northern Europe in the Early Fourteenth Century. Princeton, NJ: Princeton University Press.

Kelsey G, Constancia M, Dean WL, Feil RP \& Reik W (1999) Genomic imprinting of fetal growth. In Fetal Programming: Influences on Development and Disease in Later Life, pp. 73-84 [PMS O'Brien, T Wheeler and DJP Barker, editors] London: RCOG Press.

Keys AJ, Brozek J, Henschel O, Michelson O \& Taylor HL (1950) The Biology of Human Starvation. Minneapolis, MN: University of Minnesota Press.

Kimm SY, Glynn NW, Aston CE, Damcott CM, Poehlman ET, Daniels SR \& Ferrell RE (2002) Racial differences in the relation between uncoupling protein genes and resting energy expenditure. American Journal of Clinical Nutrition $\mathbf{7 5}$, 714-719.

Kramer MS (1987) Determinants of low birth weight: methodological assessment and meta-analysis. Bulletin of the World Health Organization 65, 663-737. 
Kramer MS (2003) The epidemiology of adverse pregnancy outcomes: an overview. Journal of Nutrition 133, 1592S$1596 \mathrm{~S}$.

Lindsay RS, Hanson RL, Wiedrich C, Knowler WC, Bennett PH \& Baier LJ (2003) The insulin gene variable number tandem repeat class I/III polymorphism is in linkage disequilibrium with birth weight but not type 2 diabetes in the Pima population. Diabetes 52, 187-193.

Lucas A, Fewtrell MS \& Cole TJ (1999) Fetal origins of adult disease - the hypothesis revisited. British Medical Journal 319, 245-249.

McCance RA (1975) Famines of history and of today. Proceedings of the Nutrition Society 34, 161-166.

Maharatna A (1996) The Demography of Famine: An Indian Historical Perspective. Delhi, India: Oxford University Press.

Melve KK \& Skjaerven R (2003) Birthweight and perinatal mortality: paradoxes, social class, and sibling dependencies. International Journal of Epidemiology 32, 625-632.

Mitchell SM, Hattersley AT, Knight B, Turner T, Metcalf BS, Voss LD, Davies D, McCarthy A, Wilkin TJ, Smith GD, Ben-Shlomo Y \& Frayling TM (2004) Lack of support for a role of the insulin gene variable number of tandem repeats minisatellite (INS-VNTR) locus in fetal growth or type 2 diabetes-related intermediate traits in United Kingdom populations. Journal of Clinical Endocrinology and Metabolism 89, 310-317.

Moore SE, Halsall I, Howarth D, Poskitt EME \& Prentice AM (2001) Glucose, insulin and lipid metabolism in rural Gambians exposed to early malnutrition. Diabetic Medicine 18, 646-653.

Neel JV (1962) Diabetes mellitus: a 'thrifty' genotype rendered detrimental by 'progress'. American Journal of Human Genetics 14, 353-362.

Newsholme EA (1994) Biochemical control logic and the metabolism of glutamine. Nutrition 10, 178-179.

Ong KK \& Dunger DB (2000) Thrifty genotypes and phenotypes in the pathogenesis of type 2 diabetes mellitus. Journal of Pediatric and Endocrinology Metabolism 13, Suppl. 6, 1419-1424.

Ong KK, Petry CJ, Barratt BJ, Ring S, Cordell HJ, Wingate DL, Pembrey ME, Todd JA \& Dunger DB (2004a) Maternalfetal interactions and birth order influence insulin variable number of tandem repeats allele class associations with head size at birth and childhood weight gain. Diabetes 53, 1128-1133.

Ong KK, Phillips DI, Fall C, Poulton J, Bennett ST, Golding J, Todd JA \& Dunger DB (1999) The insulin gene VNTR, type 2 diabetes and birth weight. Nature Genetics 21, 262-263.

Ong KK, Potau N, Petry CJ, Jones R, Ness AR, Honour JW, de Zegher F, Ibanez L \& Dunger DB (2004b) Opposing influences of prenatal and postnatal weight gain on adrenarche in normal boys and girls. Journal of Clinical Endocrinology and Metabolism 89, 2647-2651.

Paquette J, Giannoukakis N, Polychronakos C, Vafiadis P \& Deal C (1998) The INS 5' variable number of tandem repeats is associated with IGF2 expression in humans. Journal of Biological Chemistry 273, 14158-14164.

Parry-Billings M \& Newsholme EA (1991) The possible role of glutamine substrate cycles in skeletal muscle. Biochemistry Journal 279, 327-328.

Popkin BM (2001) The nutrition transition and obesity in the developing world. Journal of Nutrition 131, 871S-873S.

Popkin BM (2002) An overview on the nutrition transition and its health implications: the Bellagio meeting. Public Health Nutrition 5, 93-103.
Prentice AM (2001) Fires of life: The struggles of an ancient metabolism in a modern world. BNF Nutrition Bulletin 26 , 13-27.

Prentice AM (2003) Intrauterine factors, adiposity, and hyperinsulinaemia. British Medical Journal 327, 880-881.

Prentice AM \& Goldberg GR (2000) Energy adaptations in human pregnancy: limits and long-term consequences. American Journal of Clinical Nutrition 71, 1226S-1232S.

Ruiz-Pesini E, Mishmar D, Brandon M, Procaccio V \& Wallace DC (2004) Effects of purifying and adaptive selection on regional variation in human mtDNA. Science 303, 223-226.

Sen AK (1981) Poverty and Famine: An Essay on Entitlement and Deprivation. Oxford: Clarendon Press.

Snyder EE, Walts B, Perusse L, Chagnon YC, Weisnagel SJ, Rankinen T \& Bouchard C (2004) The human obesity gene map: The 2003 update. Obesity Research 12, 369-410.

Stead JDH, Hurles ME \& Jeffreys AJ (2003) Global haplotype diversity in the human insulin gene region. Genome Research 13, 2101-2111.

Stein Z, Susser M, Saenger G \& Marolla F (1975) Famine and Human Development: The Dutch Hunger Winter of 1944-1945. New York: Oxford University Press.

Stocker CJ, Arch JRS \& Cawthorne MA (2005) Fetal origins of insulin resistance and obesity. Proceedings of the Nutrition Society 64, 143-151.

Susser M (1991) Maternal weight gain, infant birth weight, and diet: causal sequences. American Journal of Clinical Nutrition 53, 1384-1396.

Vafiadis P, Bennett ST, Colle E, Grabs R, Goodyer CG \& Polychronakos C (1996) Imprinted and genotype-specific expression of genes at the IDDM2 locus in pancreas and leucocytes. Journal of Autoimmunity 9, 397-403.

van der Sande MA, Ceesay SM, Milligan PJ, Nyan OA, Banya WA, Prentice A, McAdam KP \& Walraven GE (2001) Obesity and undernutrition and cardiovascular risk factors in rural and urban Gambian communities. American Journal of Public Health 91, 1641-1644.

West KM (1974) Diabetes in American Indians and other native populations of the New World. Diabetes 23, 841-855.

Widdowson EM \& McCance RA (1974) The determinants of growth and form. Proceedings of the Royal Society London 185, $1-17$.

Wilcox AJ (2001) On the importance - and the unimportance - of birthweight. International Journal of Epidemiology 30, 1233-1241.

Wolfe RR, Klein S, Carraro F \& Weber JM (1990) Role of triglyceride-fatty acid cycle in controlling fat metabolism in humans during and after exercise. American Journal of Physiology 258, E382-E389.

Yajnik C (2000) Interactions of perturbations in intrauterine growth and growth during childhood on the risk of adultonset disease. Proceedings of the Nutrition Society 59, 257-265.

Yajnik CS, Fall CH, Coyaji KJ, Hirve SS, Rao S, Barker DJ, Joglekar C \& Kellingray S (2002a) Neonatal anthropometry: The thin-fat Indian baby. The Pune Maternal Nutrition Study. International Journal of Obesity 27, 173-180.

Yajnik CS, Lubree HG, Rege SS, Naik SS, Deshpande JA, Deshpande SS, Jogelkar CV \& Yudkin JS (2002b) Adipocity and hyperinsulinaemia in Indians are present at birth. Journal of Clinical Endocrinology and Metabolism 87, 5575-5580.

Zimmet P, Taft P, Guinea A, Guthrie W \& Thoma K (1997) The high prevalence of diabetes mellitus on a Central Pacific Island. Diabetologia 31, 111-115. 
https://doi.org/10.1079/PNS2005421 Published online by Cambridge University Press 